\title{
La Feminité triomphante: Surrealism, Leonor Fini, and the Sphinx
}

\author{
Alyce Mahon
}

\author{
"Have we not known for a long time that the riddle of \\ the sphinx says much more than it seems to say?"
}

André Breton, View, 1942

Mythology may be a text whose meaning remains "arbitrary, meaningless, absurd" (8-9), open to a multitude of ideological and geographic interpretations, as Claude Lévi-Strauss has argued. For the surrealists, however, it offered a fantastic discourse with which to champion the irrational. The myth of the sphinx was especially attractive, providing the perfect metatext for an exploration of forbidden desire, as well as encompassing the fantasy of the femme fatale, the potential of the city for the marvelous encounter, and a means of self-questioning by which logic and riddle could be set against each other.

Intrinsic to the surrealists' stance on the sphinx as a poetic representation was a gendered view of desire, of course. Paradoxically, woman was framed as a peculiarly initiatory and healing power on the one hand, and as a fatal seductress on the other. Her double-edged profile, encompassing life and death, allowed the male surrealist to envisage himself as poetic hero, setting out on unknown paths to find love, and facing danger and desire, whether in the city, château, forest or desert landscape. In "Discours sur le peu de réalité" (1924), André Breton fantasizes about suits of armor and woman as the holy grail, staging the challenge in the medieval château: "I stand in the vestibule of a chateau, lantern in hand, illuminating one after another the gleaming suits of armor. [...] one of these suits seems almost my size. If only I could buckle it on and thus recapture a little of the feeling of a man of the fourteenth century" (2: 17). He turns his back on the contemporary in favor of heraldry and the romance of the unknown. But alongside his romance of the artist as medieval knight is a vision of the non-western frontier that is pertinent to the fantasy of the sphinx. Breton implores: 
Orient! Victorious Orient! You who have had only a symbolical value, dispose of me, Orient of wrath and pearls! In the flow of a phrase as well as the mysterious wind of jazz, reveal to me your plans for the coming revolutions. You who are the resplendent image of my dispossessions, Orient, beautiful bird of prey and of innocence, I implore you from the depths of the kingdom of shadows! Inspire me, so that I may be he in whom there are no more shadows. (2: 28)

While Breton's “Discours sur le peu de réalité" does not present the sphinx herself, his Orientalist gaze reinforces the erotic appeal of the sphinx. Breton's vision of foreign lands complements his vision of the ideal woman: their lure lies in the fantasy of the exotic. Four years later his dark eyed protagonist in Nadja (1928) speaks to the sphinx directly. Nadja reveals many a sphinx-like trait as she and the city of Paris become one and as Breton both desires and fears her. When walking past the Sphinx Hotel in Paris with Nadja, Breton questions the master-muse relationship he shares with her and yet her potential to still him:

I have taken Nadja, from the first day to the last, for a free genius, something like one of those spirits of the air which certain magical practices momentarily permit us to entertain but which we can never overcome. As for her, I know that in every sense of the word, she takes me for a god, she thinks of me as the sun. I also remember [.... having appeared black and cold to her, like a man struck by lightning, lying at the feet of the Sphinx. (Nadja 111)

In L'Amour fou (1937), Breton takes the sphinx and the amorous quest outside the streets of Paris and into the Orient once more. He writes of a May night full of desire and perfume "in a restless murmur, vertiginous as the signal, over the silk of the deserts, of the Sphinx approaching" (Mad Love 69). Again the corporeal nature of the desert land, with undulating curves, silky surfaces and perfumed aroma, like the flesh of a nubile woman, allow Breton to simultaneously portray the male artist as valiant lover and explorer and the female as perpetually elusive. In this self-fashioning, Breton followed the writings of Eliphas Lévi (Alphonse Louis Constant, 1810-1875), the nineteenth century alchemist to whom he repeatedly returned and to whom he paid homage in his Histoire de la magie (1957). In his writings Lévi offered a Gnostic position on desire based on a fusion of Jewish, Christian, Babylonian and Egyptian elements; these helped shape many of Breton's ideas, as Anna Balakian has documented in André Breton, Magus of Surrealism (1971). Notably, Lévi conceived of desire as "overcoming antinomies: la coincidentia oppositorium, the coexistence of opposites, and the reversal of one into the other" (Balakian 36). Further, in Lévi's writings, woman was given the role of the prophet, and in replacing the French Revolution's rally cry of "liberty, equality and fraternity" with a call for "humanity, justice and solidarity," 
Lévi aligned the struggle for these concepts with, in his words, "the enigma of the modern sphynx, which must be divined or we perish" (Balakian 38). Building on such ideas, it is woman's shape-turning abilities, her allegorical guise as sphinx, siren, mermaid, beautiful girl with serpent legs, iconic Melusine or Isis, that allowed Breton to see her as a transformational power; in promoting the loss of Self in the Other she had the potential to lead man into the 'silk of the deserts.'

As Breton turned to the sphinx as a means of reinforcing his knightmuse fantasy, Max Ernst and Salvador Dalí turned to the sphinx as the seductive intermediary between gods and humans, fantasy and the real, with an emphatic Freudian emphasis on the tale. Sigmund Freud aligned the sphinx with forbidden sexuality, his peculiar focus on the sphinx's role in the tale of Oedipus Rex aligning her not only with threatening femininity but also with parricide. In The Interpretation of Dreams (1900), he describes Sophocles' Oedipus Rex as "a tragedy of destiny" (363), quickly dismissing the centrality of the sphinx to Oedipus's tale in favor of the later part of the story, when Oedipus realizes that he has killed his father and seduced his mother. This aspect of the story allows Freud to expand upon the Oedipal complex, finding a universality in the ancient Greek myth: "It is the fate of all of us, perhaps, to direct our first sexual impulse towards our mother and our first hatred and our first murderous wish against our father. Our dreams convince us this is so. King Oedipus who slew his father Laïus and married his mother Jocasta, merely shows us the fulfillment of our own childhood wishes" (364).

However, it is the sphinx who leads to the denouement of the tale. Her riddles terrorize the city of Thebes and her seductive but hybrid form (head and bust of a woman, body of a lion, wings of an eagle) denotes her sexual allure and threat simultaneously. Many brave men have journeyed to her lair at the entrance to the city of Thebes only to fall victim to her riddles. While Oedipus rises to power by solving the sphinx's riddle, his success is tarnished: his triumph over the sphinx allows him to take the city and its newly widowed queen (his mother), but ultimately it is a conquest built on parricide and incest. The sphinx's death paves the way for Oedipus's glory and his later tragedy. His knowledge and insight allow him to solve the riddle and yet, ironically, he is exposed as ignorant and blind.

The sphinx's power and physiognomy, as both female and male, human and beast, reinforce the vital role of the sexes and the danger of unlawful union which is central to the tale. Max Ernst and Salvador Dalí follow this Freudian interpretation of the myth. Dalís Remorse, or Sphinx Embedded in the Sand (1931) depicts a solitary female figure, embedded in sand up to her waist, her back to the viewer. It alludes to Albrecht Dürer's Melancholia I (1514), the forlorn female figure of the German master similarly turning away from the light and thus symbolically reinforcing the power of the 
imagination over the male characteristic of reason. In a desert landscape and facing a rugged rocky frontier, identifiable as Dali's favored Catalan terrain, the sphinx symbolizes the struggle with the mother figure and, by extension, impotence. For Dalí, the sphinx was both bad mother and praying mantis: a threat to the male, and a bearer of death - or in Carlos Rojas' words "the mother was the executioner who induced him to the sin of having been born" (127). In Dalí's rich Freudian symbolism, the rock face denoted his own peculiar obsession with masturbation. He named the rock at Cape Creus the "great masturbator" and enjoyed Breton's discovery of an island called "Sein" with its rock called "the sphinx". Accordingly, in his painting, the sphinx's position opposite a craggy rock face reinforces his use of the myth to explore sexual taboo (Rojas 126-27).

Max Ernst presents the sphinx as androgynous creature in his collage novel Une Semaine de bonté (1934). In one plate the sphinx peers into a railway carriage at a man-beast dressed in suit and bowler hat. Beside him we see the legs of a body lying on the carriage floor, a sign of death that leads the eye to notice mad dogs tearing at the side of the sphinx's face in the desert outside. The vehicle's nineteenth-century interior and the beauty of the desert outside the window are here dramatically undermined by Gothic horror. The sphinx is staged in the desert and, surrounded by a veil of terror, she brings death and destruction. The choice of setting reminds us of the difference between the Egyptian sphinx, who protects the pyramids in the bleak desert, and the Greek myth, where the sphinx prevents entrance to the city of Thebes. As Jack Spector has observed, the distinction between the Egyptian and Greek sphinxes was well known to Freud, whereby "the Egyptian sphinx is almost invariably a symbol of the king"; yet the psychoanalyst conflated both lands in making the sphinx the symbol of the father figure in his Oedipal scenario (72-73). In "Dostoievsky and Parricide" (1928), Freud clearly but incorrectly refers to Oedipus's sphinx as a symbol of the father, despite his knowledge of both Egyptian and Greek sphinx iconography. In so doing, Freud undermines the sphinx's female profile and prowess. He presents the sphinx as female and deadly (where it is male and protective in its first, Egyptian form), and yet aligns her slaying with that of the father (as if she were male and king-like). Freud's own personal collection of art included Egyptian artifacts, an ancient Greek terracotta sphinx, and a copy of JeanAuguste-Dominique Ingres' Oedipus and the Sphinx (1808) (See Burke). In Ingres' painting, the young and calm Oedipus stares the small female sphinx in the eye as she guards her cave, one outstretched finger seeming to suggest he is about to caress her rather than use the spears he holds in his other hand. It is an image that presents the sphinx as femme fatale, but Oedipus is undoubtedly the focus of the narrative. This emphasis reminds us again of the gendered bias underpinning the male surrealist's quest for the sphinx. 
They were not alone in this bias. As Simone de Beauvoir points out in The Second Sex (1949), the sphinx became the focus of widespread artistic and literary exploration from the mid nineteenth century through to World War II - a period in which "Man is delighted by this very complexity of woman [...] Is she angel or demon? The uncertainty makes her a Sphinx" (224). ${ }^{1}$ From the famous Sphinx brothel in Paris to the amorous pursuit of the femme fatale, the sphinx allowed for poetic indulgence in feminine mystery and so she "was all the rage in plays, poetry and song" (224). Effectively, as Elizabeth Wilson argues in The Sphinx in the City: Urban Life, the Control of Disorder, and Women (1991), the sphinx and modernity were aligned as they were perceived as sharing an element of seduction and threat. Woman's presence in the modern city became problematic - as we find with Breton's Nadja, her status was often suspect, poised between prostitute and fallen woman. Or in Wilson's words, "Woman is present in cities as temptress, as whore, as fallen woman, as lesbian, but also as virtuous womanhood in danger, as heroic womanhood who triumphs over temptation and tribulation" (6).

If we compare the aforementioned representations of the mythical creature to those by the woman surrealist Leonor Fini, however, a different sphinx is found, one who stands as a mistress of riddles but also as a guardian of life. Fini presents a peculiarly Egyptian sphinx, expanding the sphinx's mythology for surrealism so that the feminine denotes humanism rather than the simple threat of death. Fini's paintings emphasize the regenerative power of the sphinx and her ability to return the individual to his/her primordial nature. Her fascination with the sphinx predated her affiliation with surrealism. As she explained to her biographer Peter Webb, her obsession with the sphinx went back to her childhood: "I remember I wanted to be like the sphinx" (Webb 102). Webb documents how as a young girl she enjoyed the Egyptian sphinx of Miramar Castle and the caryatids that adorned the Eden cinema in Trieste (where she lived from the age of two with her mother Malvina, who had fled her husband Herminio Fini in Buenos Aires). As Fini claimed to have appreciated the sphinxes as "images of femininity triumphing over a city" (11), Webb observes that the sphinx played a major role in her art and life. But her fascination with the sphinx went beyond a trope or persona; in her obsessive return to the sphinx during and in the aftermath of World War II we may see her sphinx as an answer to Breton's war-time call for a new myth, as well as a proto-feminist icon for surrealism. From The Shepherdess of the Sphinxes (1941) to her voyage to Egypt ten years later, Fini presented the Egyptian sphinx as a matriarchal

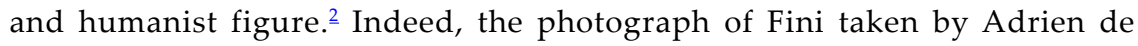
Menasce beside the Great Sphinx at Giza reveals the artist's relationship with the triumphant creature and its role, in turn, for surrealism: Fini poses so that we only see her upper torso, her eyes looking down as she stages herself as the mirror image of the pensive and protective sphinx. 
When she left Trieste for Paris in 1931 and met the surrealists there, Fini was already well versed in Freud. In an interview with surrealist poet Edouard Roditi in 1963, she spoke of the surrealists' surprise at her learning and that, "I, an Italian girl, had already read all the published works of Kafka in German as well as Jensen's Gradiva and most of the writings of Freud, all of which were as then quite new in Paris, but, in Trieste, had been part of our heritage as Austrian citizens until the end of the First World War" (Roditi 21). She was also familiar with Jules Michelet's 1863 study La Sorcière, once describing Michelet's witches as "beautiful, rebellious, clever" (Fini 44) an appreciation central to her portrayal of the sphinx, as we shall see. Fini was quickly embraced by the surrealist circle. Paul Éluard wrote a poem entitled "Le Tableau Noir", dedicated to Fini and evoking "La demoiselle inopportune" (The inopportune young lady) (Éluard 203-04), which was reproduced in Fini's first American exhibition at the Julien Levy gallery in New York in the autumn of 1936. This was a joint show with Max Ernst, a coupling which suggests she was held in high esteem by both Levy and Ernst. A critic writing in The New York Times in November 1936 notes that Levy described Fini as a "SurRaphaelite, because she reminds him of Uccello, of Pollaiuolo and of those nineteenth century brotherhood masters" (Jewell 22). Fini exhibited with the surrealists for the first time that year in Paris too, contributing a found object to the 1936 Surrealist Exhibition of Objects at the Charles Ratton Gallery. Her object was a fossilized book, supposedly found in the sea: its cover was matted with seaweed and shells such that only part of its title, "Columbus", was visible. $\frac{3}{\text { An }}$ armoire she designed for the opening show at Leo Castelli's new Galerie Drouin in Paris in May 1939 better revealed her obsession with female viragoes however: the doors were graced by two winged angels, their hair coiling over the top of the wardrobe.

Prior to Fini's visit to Egypt in 1951, she depicted herself as a shepherdess ruling over a harem of sphinxes in the oil painting The Shepherdess of the Sphinxes (1941). The scene is set in an apocalyptic landscape, the only signs of natural life being discarded flowers and bones. Eight sphinxes populate the landscape as the shepherdess looks away from the spectator, leaning on her staff, naked apart from a metal thong-like garment. Peggy Guggenheim came to own this painting through Max Ernst, who saw it in Fini's studio in Monte Carlo in 1941. He encouraged Guggenheim to buy it before setting sail for America from Marseilles that year. In her memoirs, Guggenheim is far from generous in her account of the purchase, despite the fact it would win critics' praise when exhibited soon after in New York. She claimed she bought it as "Max adored her and wanted me to." To Guggenheim, "Leonor Fini was a great pet of Max's [...]. He had Leonora Carrington and Leonor Fini and was perpetually trying to further their careers [....] Laurence, Marcel and I did not like [Fini's] spoiled vedette manner" (235). Ernst's opinion clearly swayed Guggenheim and appears to have swayed Breton too. Guggenheim continues "Later in New York, Breton very much objected to its being in my 


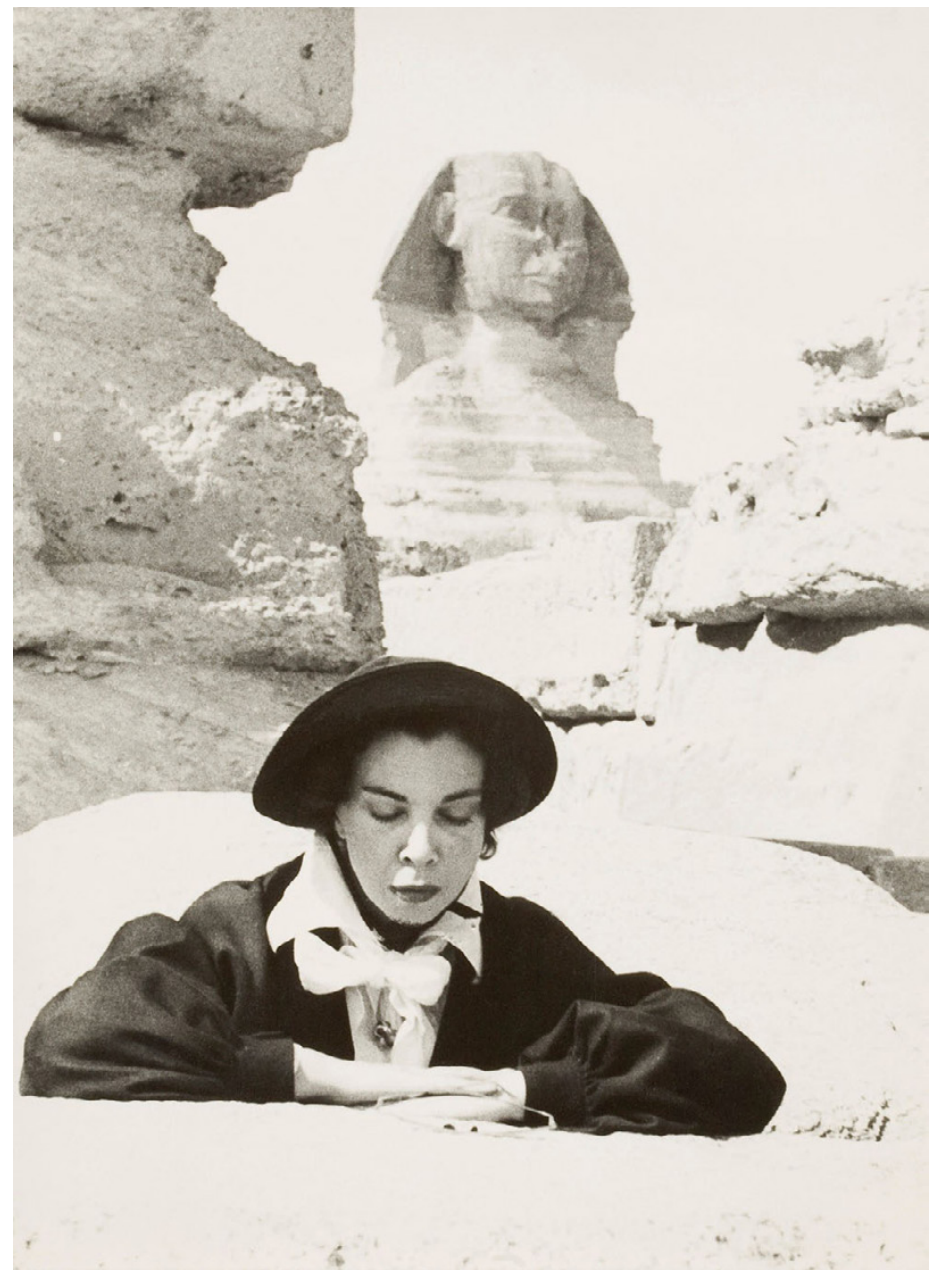

Figure 1: Adrien de Menasce, Photograph of Leonor Fini, Egypt, 1951, gelatin silver print, (C) Foto: Galerie Minsky, Paris.

collection, but because of Max he couldn't do anything about it" (235). Certainly, Ernst admired Fini and her art, but it might be fairer to say that he appreciated and encouraged the work of women artists who shared his own interests in magic and alchemy. Writing for a 1960 exhibition of Fini's in London, Ernst emphasized the vertiginous quality of Fini's paintings, a quality which is sphinx-like in mood and technique:

Her paintings are made up of vertigo. Canvases which, at first, seem to be evil, full of corpse-like dissolution [...] After the first dizziness, those who are bold enough let themselves be drawn by the inverted vacuum, and for their exorbitant reward, they discover 
that this abyss, which seems dark (glutinous), is inhabited by the most astounding collection of legendary beings, that it is free from every dangerous, every filthy thing. Miraculous plays of darkness and light are given ultimate expression in the pulsating pearly colors of this chimerical flesh, that resembles the bifid love-making of sphinxes. (Ernst n. pag.)

Despite her obvious jealousy, Guggenheim did exhibit The Shepherdess of the Sphinxes in the inaugural exhibition at her new Art of this Century Gallery in New York in 1942 and again in her 1943 show An Exhibition by 31 Women, which included artworks by other surrealists, notably Leonora Carrington, Meret Oppenheim, and Dorothea Tanning. In his essay "Shepherdess of the Sphinxes", published in View in June 1943, Leon Kochnitsky singled out Fini's painting, reproducing an image of it alongside an essay in which he asserted that "Improvisation, luck and instinct play important roles in a woman's art" (49). Kochnitsky described Fini in terms which were surely progressive in 1943, however patronizing they might appear to readers today: he described her as a woman who paints like a man, following the path of "Berthe Morizot" (sic), with a "highly developed sense of fantasy, a gift for ornament, a talent for sheer surprise and prodigious capacity for metamorphosis" (66). Interestingly, Kochnitsky acknowledges that Fini combines the portrait with the fantasy setting in her work and is herself "the imperious shepherdess of a herd of sphinxes [who] really creates a new myth; these are other Arianes, Andromedas, Cleopatras - although they do not have these names". In 1955, Marcel Brion also noted how Fini explores the fantastic in a different manner from her male contemporaries, in drawing on "a mythology lost and rediscovered" (N. pag.). ${ }^{4}$ He identified the cat as the animal who best characterizes her mythology - her cat symbolizing "all of nature, non-human, extra-human, animate or inanimate" - and he argued that her mythological creatures are always feminine ("monsters are always monstresses") (N. pag.). $\frac{5}{2}$ As a result, for Brion, Fini's is an emphatically matriarchal view of myth and the universe: "It is not the sign of a dominant femininity, but of membership of an ancient cult, of a most singular revival, characteristic of the magical foundation of an art linked to the primordial beliefs of a growing humanity" (N. pag.). ${ }^{6}$

Fini's paintings of the sphinx must be viewed as part of the surrealists' search for a new myth, notably the myth of the "Great Transparent Ones", written of in Breton's 'Prolegomena to a Third Surrealist Manifesto or Not' (1942). Here Breton stated that myths would "mysteriously reveal themselves to us" (293), and would result in new realities. That year, in the April 1942 edition of View, Nicolas Calas wrote of the "diabolical" woman in surrealism, the "woman in our dreams" - a woman he claimed to find in the art of Ernst and the person of Fini, writing "Leonor Fini, one of the most inspiring women of our time, walks in the garden of Ernst's paradise" (21). 
But Calas' ideal woman is ambivalent: when she stands in water, she does so not as Botticelli's Venus does, but in a way that denotes "dryness and nudity, provocation and protection, virginity and maternity" (ibid.). Calas' essay was illustrated with a photograph of a clothed Fini in a bath, posed with one arm behind her neck, and staring out at the photographer. Fini may have spent the war years in Europe but her sphinxes and 'diabolical' profile were still present in the surrealist circle in exile. Her art and persona complemented the surrealist search for myth, and the intrigue with the diabolical witch, written of in Breton's Anthologie de l'humour noir (1943) where he acknowledges Jules Michelet, "who so beautifully rendered the Witch" in La Sorcière (1862). It also complemented the concept of initiation of which René Guénon writes in his Aperçus sur l'initiation (1946), a text favored by the surrealists and drawn on for their 1947 international exhibition devoted to myth. In that show initiation was presented as a rebirth and myth as a vital element to those processes. ${ }^{\underline{7}}$

Male and female surrealists agreed that the sphinx was the mythological creature they most admired. In 1943 the sphinx was hailed as the pre-eminent mythological creature in the journal $V V V$. Twenty-one surrealists in exile were asked to rank fifteen mythological creatures in order of their "attraction" the sphinx received the highest rating, with six of the respondents ranking her first ("Concerning" 166-67). Among the respondants was Leonora Carrington (ranking the sphinx sixth), a close friend of Fini's, who later, in a response to a series of questions on magic which Breton included in his 1957 volume L'Art Magique, further reinforced the significance of the sphinx for the movement. In her reply, Carrington saw the artist as modern day magician or explorer on a "strange magic ocean," searching for "salvation" for his "diseased planet," and concluded that the sphinx was the magical creature who could lead the way (Carrington 281). Her polychrome wooden sculpture Cat Woman of 1951, which is just over two meters in height and decorated with hieroglyph-like figures and landscapes from the torso to the feet, exemplifies her admiration of the Egyptian guardian, though she leaned more towards Celtic and Mexican mythology in her paintings.

Fini thus shared her fellow surrealists' admiration of the sphinx, but hers was a peculiarly matriarchal mythology which advanced a humanist and proto-feminist surrealism at a time of war. Fini owned a copy of Grillot de Givry's study Le Musée des sorcières, mages et alchemistes (1929) (Webb 49). In this book much is made of the power of sorcerers to change into animals "to escape more readily from those who tried to defeat their intentions," and here the hermetic androgyne, fusing Sun and Moon, man and woman, is documented in a history of text and image from the Middle Ages to the nineteenth century (Givry 69). She also turned to Michelet's La Sorcière for a female type who spoke to magic, animal magnetism, and clairvoyance. In his study, Michelet presents the witch as a hermit and an outcast, either 
mocked by children and townsfolk or feared for her power to "derange the senses" (76). The witch was aligned with Nature, but Nature in all her unruly isolation; thus the desert or forest - that is, unmapped spaces - offer the perfect settings for an encounter. Michelet writes: "Her place of abode? It is in spots impracticable, in a forest of brambles, on a wild moor where thorn and thistle intertwining forbid approach. The night she passes under an old cromlech. If anyone finds her there, she is isolated by the common dread; she is surrounded, as it were, by a ring of fire" (12). Michelet also observed "The Italian women often became cats, and gliding under the doors, sucked, they said, the blood of children" (107), an observation which seems especially pertinent to Fini, an artist reared in Trieste and for whom the cat was so important, as is clear from her self-portrait as a feline goddess, The Ideal Life (1950).

In her art Fini gives voice to the sphinx, not Oedipus, refusing to see her and womankind as a problematic 'riddle' that deserves no further attention, as in Freud. When Fini displays the male before the sphinx he is not poised for action, sexual or murderous, but asleep. While acknowledging Greek mythology and the bare-breasted malevolent sphinx, Fini embraced her Egyptian counterpart. She presented a sphinx who is often an androgynous and benevolent figure, frequently adorned with Oriental jewels and headdress. Fini presents the sphinx as Nature empowered but also poised against 'civilization' and all its violence. Thus in Sphinx Philagria (1945) the sphinx appears in a Bosch-like landscape, with surrounding flora and fauna rendered in exact detail, including skulls, with insects crawling in and out of them. Her youthful fertility, symbolized in long luscious hair and pert breasts, stands in stark contrast to the death about her and the ominously overcast sky that hangs over a cityscape in the rear of the composition. Woman and Nature are one, as woman is rooted to the soil. Together they symbolize the potential for life despite death.

In Little Guardian Sphinx (1943-44), the Egyptian version is again represented, as the sphinx is posed in a recumbent position, typical of those found by archaeologists at temple sites, and is recognizable as a personification of female deity in a land where the cat signified the female. Where the sphinx of Greek mythology was a monstrous threat to stability, the sphinx of Egyptian mythology was a protector, the guardian of the temples of the Nile Valley, the figure who guarded the entrance to death. The face of the sphinx might be male or female. In having the body of a lion and the wings of an eagle the sphinx conflated the masculine and feminine: in alchemical symbolism the lion is associated with the earth and Philosophical Sulphur, the masculine stable substance, and the eagle with Philosophical Mercury, the feminine volatile substance (Warlick 11). Fini's sphinx denotesruth, symbolized by the broken egg shells about her which suggest the egg shaped oven, the athanor, in which Mercury (symbolizing the feminine, water, nurturing principle) and Sulphur (symbolizing the male, fire, the intellect) are combined to make the 


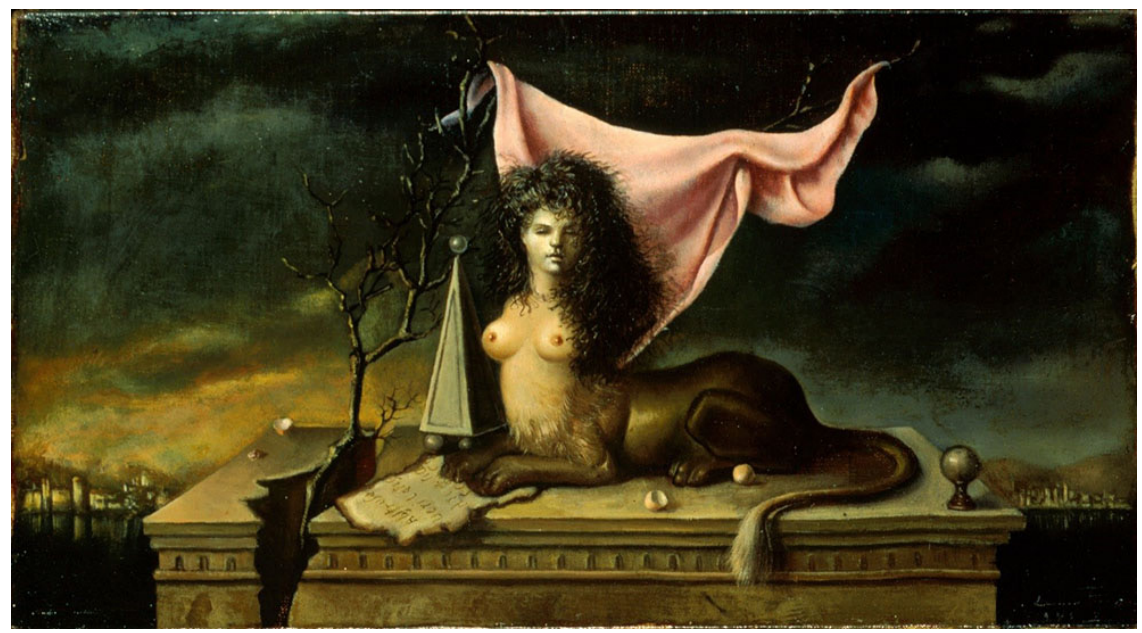

Figure 2: Leonor Fini, Little Guardian Sphinx, 1943-44, oil on canvas, location unknown, (C) ADAGP, Paris and DACS, London 2012/Galerie Minsky, Paris.

Philosopher's stone. The sphinx may, by extension, be seen as the marriage or fusion of these qualities, as the birth of the couple, the androgyne, or the 'Great Work'. The triangular object beside her further represents a fusion of mind, body and spirit in alchemical symbolism, and so perfection beyond sexual difference.

When compared to a traditional portrait of the sphinx, such as Gustave Moreau's Oedipus and the Sphinx (1864) - a Symbolist variation on Ingres' representations by an artist much cited by Breton in L'Art magique - Fini presents a radically different iconography, from a female perspective. In Moreau's painting the sphinx thrusts herself on the young Oedipus in a craggy landscape, their gazes locked as the spectator ponders their precarious footing. The sphinx's past suitors lie dead beneath her; she is death disguised in feminine artifice. In contrast, Fini rejects the characterization of the sphinx as predator and never positions the male as stronger, more rational or surefooted. Rather, if her sphinx lures and engulfs the male, it is so that rational man loses himself to her superior powers, surrendering to the abyss that Breton never braved in Nadja. Indeed, if the male artist's fantasy of the sphinx necessitated an outsider, prostitute, or voluptuous threatening force, Fini presents her as an emblem of humanism itself - classical mythology allowing for the exploration of man's animal nature as much as that of woman. While there are no overt references to the war in these works, Judith E. Bernstock has documented that the humanistic implications of myth allowed modern artists to turn to mythological characters as metaphors to condemn fascism, war, and man's inhumanity to man (see Bernstock 153-83). Bernstock does 
not consider the contribution of women surrealists to this genre, nor does she focus on the sphinx, but her overview makes the important point that artists "used mythology to illuminate the present" (154). Fini's sphinx should be viewed as an assertion of such humanism at a time of brutality, as a symbol of good and evil at a time when world events forced the individual into a state of existential self-questioning.

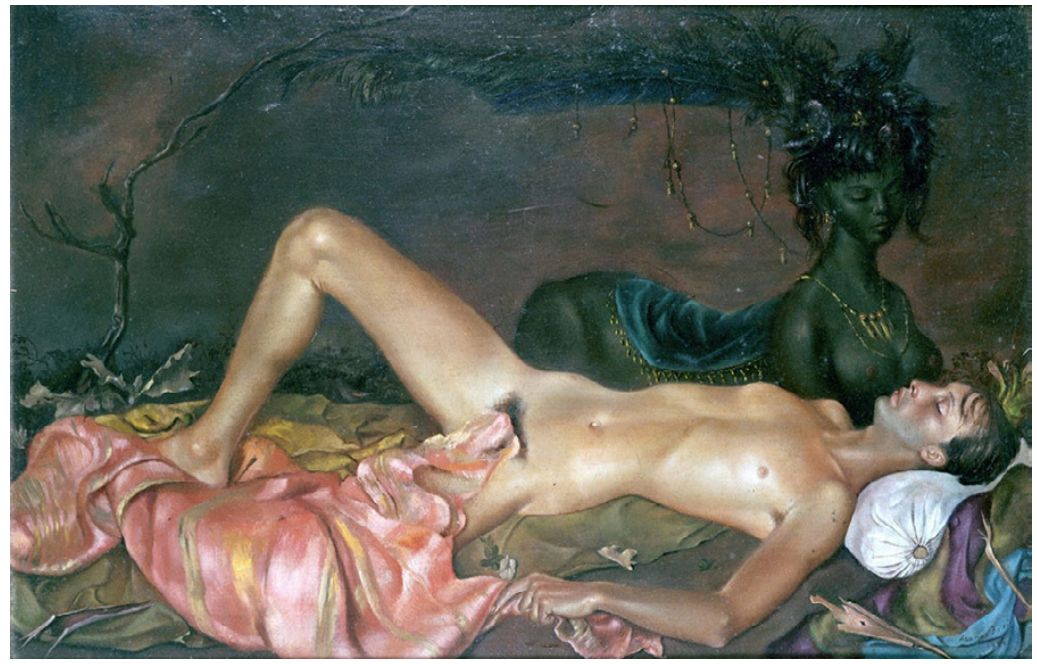

Figure 3: Leonor Fini, Chthonian Deity Watching over the Sleep of a Young Man, 1946, oil on canvas, location unknown, C ADAGP, Paris and DACS, London 2012/Scala, Florence.

The painting Chthonian Deity Watching over the Sleep of a Young Man (1946) certainly presents the male hero/Oedipus in radically new terms. He lies exposed and vulnerable before a bejeweled black sphinx. In earlier versions of this composition, Sphinx Amalburga (1942) and Woman Seated on a Naked Man (1942), the female again rests on the male nude. In the former, he is fully naked, the sphinx holding his limp body and cradling his head as if he is dead. In the latter a new female type is again asserted as the male is staged as the nude object of desire. The clothed female suggests the sphinx narrative in her reflective mood and in looking toward a landscape in the distant horizon line. Typical of northern Renaissance backgrounds, the detail of this vista, coupled with the sleeping young male draped in a sienna-colored sheet, suggest that she reigns over nature, the land, and the passions.

Fini's model for Chthonian Deity Watching over the Sleep of a Young Man was Sforzino Sforza, with whom she began a relationship in Rome in 1945. The model for the sleeping beauties of 1942 was the half-Greek, half-Ethiopian film-maker Nico Papatakis, whom Fini first painted in 1941 while living in Monte Carlo. In his memoirs, Tous les Désespoirs sont permis (2003), Papatakis 
admits his embarrassment at being asked to pose naked by Fini, but in the context of Fini's oeuvre none of these male beauties should be viewed as erotic objects per se - they go beyond personal desire and offer a transgressive restaging of the sexes (see Webb 88). As Whitney Chadwick notes in Women Artists and the Surrealist Revolution (1985), the reclining figure in Chthonian Deity Watching over the Sleep of a Young Man (1946) parodies Lucas Cranach's Nymph of the Source (1509), reversing the passive elongated female nude with a male one (Chadwick 123). Though Chadwick acknowledges the painting as a reinterpretation of traditional sexual roles, she does not seem convinced that it challenges the problematic of the erotic female as the key to (male) surrealism head on; it seems to fall within the trend of many other works by women surrealists she addresses in her book in approaching "the issue of eroticism obliquely." However, given that Fini's first title for this painting was Sphinx amoureux and that she changed it to Amalburga, a term she found in a nineteenth-century almanac of mythological and religious names in Greek, Latin and Hebrew, this work may be seen as an assertion of a female

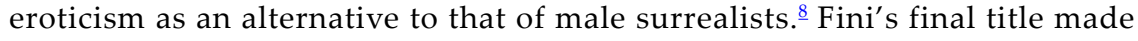
clear her sphinx was a 'protector' and was active - never passive - in the sexual dynamic.

Further, as Rozsika Parker and Griselda Pollock point out, Chthonian Deity Watching over the Sleep of a Young Man (1946) may be read as a variation on Anne-Louis Girodet-Trioson's Sleep of Endymion (1791), a tale from Greek mythology where the male also sleeps and is enjoyed by the female gaze (140). In Girodet-Trioson's painting, the goddess Diane, disguised as a moonbeam, caresses the naked body of a beautiful and mortal young shepherd with rays of light. As the encounter occurs at night when desire knows no bounds, it may be seen to presage surrealism's faith in a revolution by night. More significant, however, is the framing of the male. In her painting, Fini presents the nude male as a vulnerable, androgynous creature to offer an alternative sexual dynamic. Fini stated in an interview with Chadwick in June 1982 (St Dyé-sur-Loire) that "The man in my painting sleeps because he refuses the animus role of the social and constructed and has rejected the responsibility of working in society toward those ends" (Chadwick 188). In this painting she presents a "soft" masculinity, to borrow Abigail Solomon-Godeau's term, a feminine male in touch with his feminine anima. ${ }^{9}$ Fini stages woman as an alternative path to the destroyed world of man. In a 1993 interview with Webb, Fini said of the woman who confronts the viewer with a steady gaze in The Ends of the Earth (1948): "She is woman, symbol of beauty and deep knowledge [...] the essential element of life, the primeval material, because she knows how to survive the cataclysm" (Webb 143). 


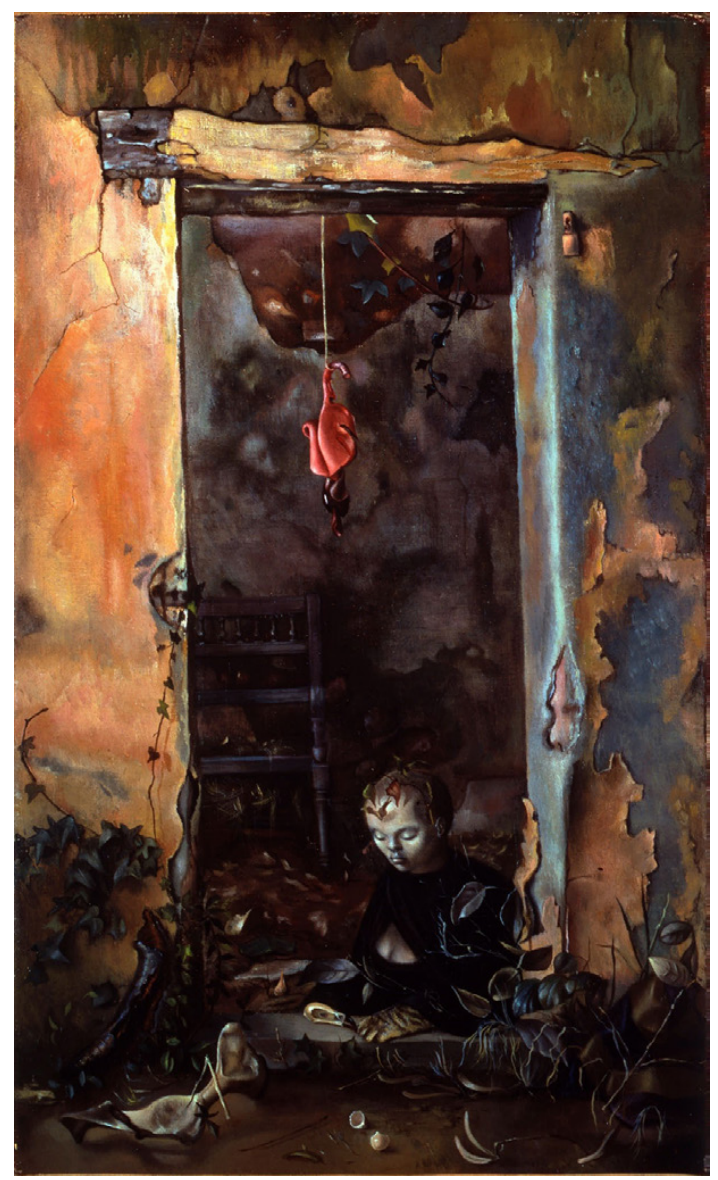

Figure 4: Leonor Fini, Little Hermit Sphinx, 1948, oil on canvas, Tate Modern Collection, London, (C) ADAGP, Paris and DACS, London 2012/Galerie Minsky, Paris.

Little Hermit Sphinx of 1948 further reminds us of the matriarchal emphasis of Fini's imagery and how the sphinx is frequently posed in a reflective, existential manner in her oeuvre Fini portrays a little sphinx in the doorway of a ruined building with bones and a broken eggshell in the foreground. Her gaze is reflective as her eyes look not at the viewer, as in most sphinx images, but down at her paw, which touches a small skull. Her head is shaved, a sign that she is a priestess, a guardian in Fini's personal symbolism. The painting was made after Fini had surgery on her bladder and uterus to remove a cancerous tumor, which left her unable to bear children. The artist did not lament the loss, stating in her 1993 interview with Webb: "The thought of having children horrified me" (Webb 133). That said, 
while the egg denotes alchemical fusion in surrealist imagery, she did admit to Webb that the broken egg shells had some personal significance: "They represent destruction. It was no longer possible for me to have children, therefore I thought the eggs contained children" (Webb 135). With a deflated pink organ-like object dangling from the door frame above the sphinx, the painting is especially macabre as the shorn sphinx and barren setting seem to reflect each other.

In their fusion of the personal and the political these sphinx paintings must be appreciated as proto-feminist, offering a female interpretation of the riddle of the sphinx and extending surrealist mythology beyond its focus on the master-muse or Oedipal scenarios. The erotic is staged in Fini's work so that the power struggle between the sexes, as played out in mythology, is questioned. Pierre Borgue observes in his 1983 study Leonor Fini, ou le théâtre de l'imaginaire, there is an immediately recognizable pose and theatricality about Fini's canvases, characterized by a mood of "emmurement" or numbness (36 and 39). This mood of erotic stupor or numbness fits Fini's images of sphinxes bearing down on their male prey, where the spectator seems witness to an in-between state or act. As we have seen, the vertiginous nature of this mood, poised between life and death, was recognized by Ernst in 1960, and it exploits Freud's and the surrealists' use of the uncanny to portray the meeting of Eros (the life drive) and Thanatos (the death drive). But hers is always a peculiarly female stance on eroticism.

Fini was fascinated with the Marquis de Sade, and the limits of eroticism as tested in the Sadean genre are revealed in these sphinxes too. At the time when she was obsessively returning to the sphinx, Fini produced twenty-two full page drawings and two cul-de-lampe drawings of explicit sexual detail for a luxury edition of Sade's Juliette, published in 1944. Her ink and wash drawings depict women bearing whips, enjoying lesbian orgies, and flaying male victims, in keeping with Juliette's libertine character. Alberto Moravia praised the illustrations in 1945:

Not only has she recaptured the mixture of eighteenth-century grace and fury, of systematic cruelty and elegance, of reason and dream, that are proper to the author of Juliette, but she has also given the text an interpretation of her own, complete and free. The desperation and the sadness, the macabre pleasure and the unhealthy monotony of the mechanics of eroticism are represented with real force in these insatiable nudes, in these faces with their veils of black melancholy. (qtd. in Webb 112)

This unique interpretation of sexual violence is equally apparent in Fini's illustrations for a luxury edition of the Sadean novel Histoire d'O, published by Le Circle du Livre Précieux in 1962. First published in 1954 under the pseudonym Pauline Réage and recounting the tale of the sexual enslavement of a beautiful young photographer in a château outside Paris, the novel was 
often presumed to have been penned by a surrealist and was listed by Breton in a surrealist calendar of events in 1955. It was not until 1994 that the true author, Dominique Aury, stepped forward. $\stackrel{10}{ }$ The collaboration between Fini and Aury was especially fitting as Aury, a member of the French Resistance during the war, had been influenced by Fini's paintings and theatrical costumes in her portrayal of $\mathrm{O}$ in the novel. Indeed, an owl mask which $\mathrm{O}$ wears in the narrative was specifically inspired by an owl mask Fini wore for a 'Bal des Oiseaux' in Paris in December 1948 (Webb 126-27). In the final scene of the novel, $\mathrm{O}$ is humiliated while wearing such a bird mask, as she is led by a chain by her "masters", René and Sir Stephen, to "a little cloister with Renaissance arcades" within which a crowd of people watch as she is verbally and physically abused and then "possessed" by both men (Réage 258-59). During this humiliation, in which $\mathrm{O}$ comes to realize her abjection, the mask both hides her identity and leads her to self-recognition. Given its theatrical and metaphoric role, it is not surprising that the plumed mask dominates Fini's preparatory drawings and final ink washes for the novel. Her staging of the sexes is also crucial. The male figure in her lithographs is archetypal: statuesque, strong, phallic. The female figure bears the hallmarks of Fini's theatrical illustrations, with a nubile body, elongated legs and waifish, wideeyed expression. Fini's one portrait of $\mathrm{O}$ is reminiscent of her pen and ink study of Medusa of 1950: O's mouth acts as a symbol for her being, wailing in the midst of a black wash, reduced to an orifice. While Fini portrays $O$ as a willing victim of the violent male, in her choice of palette and frequent recourse to black ink washes around the female form she also evokes a sense of repressed rage or desire. In 1970, she explained that the novel appealed as a book "that possesses the virtue of describing things that are painful and strange", though she admitted to identifying more with the sadistic men than with $\mathrm{O}$, their willing victim (Perlman qtd. in Webb 231). Her exploration of the dialogue between the sexual master and slave resonates with her revision of the struggle between male and female in the mythology of the sphinx, as part of a wider assertion of liberated female sexuality.

Fini's illustrations for Aury's Sadean book also support Xavière Gauthier's analysis of the sphinx in culture as representing a sexual jouissance that is both sexual and sadistic (Gauthier 47). Gauthier views Fini's art as a conscious stance against traditional maternal iconography in its promotion of sexual liberty. Gauthier cites a letter she received from Fini on 5 September 1969 in which the artist admitted to a long-standing fascination with Lilith, the anti-Eve figure, and in which she claimed that "I find physical pregnancy instinctively repugnant" (74). .11 Having produced an oil painting entitled Woman Strangling her Child in 1933, having claimed to Webb that her father remained a "mythic person" in her life (Webb 25), and having rejected the role of mother herself, it is perhaps not surprising that Fini would be obsessed with a myth in which the sacrifice of the child as well as the sacrifice of the 
father plays so momentous a role. But within the larger frame of surrealism's history this admission again allows us to view the sphinx as a conscious re-writing of the femme fatale and as the promotion of a new matriarchal mythology in which woman controls her sexuality.

Much as Lévi-Strauss argued that myth should be read as an open "orchestral score" (39-40), the myth of the sphinx offered surrealism many narratives, from an exploration of desire to existential anxiety. In the art of Fini the sphinx interrogates gender stereotypes, from the muse to the maternal, and offers an iconography which is transgressive in going beyond woman as source of male creativity or as a source of procreativity alone. Fini was passionate about the writings of Nietzsche, and as a young girl was presented with a copy of The Gay Science (1882) by metaphysical artist Arturo Nathan. Her paintings speak to Nietzsche's view of the sphinx in Beyond Good and Evil (1886). There he wrote, "Which of us is Oedipus here? Which of us sphinx? It is, it seems, a rendezvous of questions and question marks" (15). When it was put to Fini in an interview in 1967 that "you have revolted more against a society that exalts virility than against men", Fini agreed "Yes, of course. I am against society, eminently asocial, and I am linked to nature like a witch rather than as priestess, as I've told you. I am in favor of a world where there is little or no sex distinction" (Jelenski 3). The sexual hybridity of the sphinx, the role of the sphinx as guardian and protector, as a natural and erotic force in charge of her powers in the midst of chaos and waste, all reinforce this position. The sphinx's triumphant femininity truly emerges and enchants in Fini's paintings, but always with a view to leading to a better way in a world traumatized by war.

\section{Notes}

1. See also pages 261-62 where de Beauvoir notes the significance of the sphinx for Breton, writing of him as a Dante in search of his Beatrice. The sphinx, she argued, appealed as "To throw oneself into the mystery is the only way to find out about it."

2. Fini spent several months in Egypt in 1951 and had a joint exhibition with Marquis Stanislao Lepri at the Salon Isis in the Shepheard Hotel in Cairo and the Lehman Gallery in Alexandria, exhibiting such works as Sphinx Philagria (1945) and The Ideal Life (1950), as well as portraits.

3. See photograph of Fini's 'objet trouvée', in Cahiers d'art, 11.1-2 (1936), N. pag.

4. "une mythologie perdue et retrouvée..."

5. “...toute la nature non-humaine, extra-humaine, animée ou inanimée... les monstres sont toujours des monstresses."

6. “Ce n'est pas le signe d'une dominante féminine, mais d'une appartenance à un très vieux culte, à la plus singulières résurgences, caractéristiques de 
soubassements magiques d'un art rélie aux primordiales croyances de l'humanité naissante."

7. I discuss this international exhibition of 1947 at length in my book Surrealism and the Politics of Eros 1938-1968, 107-141.

8. Webb notes that her reference book was Rafaello Mazzoni's Almanacco perpetuo, Rome, 1939 (99).

9. In this reading of Chthonian Deity Watching over the Sleep of a Young Man, I differ from that of Georgiana Colvile, who concludes that this painting is "more threatening than protective" (176).

10. Dominique Aury admitted her authorship in an interview with John de St Jorre in 1994, in preparation for his book The Good Ship Venus: The Erotic Voyage of the Olympia Press, London: Hutchinson Press, 1994.

11. "Les maternités physiques me répugnent instinctivement." In Catholic teaching, a distinction is often made between physical motherhood and spiritual motherhood, as in the case of those women who follow the religious life and are viewed as the 'Bride of Christ.' For a discussion of the recent use of these terms by Pope John Paul II see Beattie 74-76.

\section{Works Cited}

Balakian, Anna. André Breton, Magus of Surrealism, New York: Oxford UP, 1971. Print.

Beattie, Tina, God's Mother, Eve's Advocate, London: Continuum, 2002. Print.

Beauvoir, Simone de. The Second Sex. Trans. and ed. H.M. Pashley. Harmondsworth: Penguin, 1982. Print.

Bernstock, Judith E. "Classical Mythology in Twentieth-Century Art: An Overview of a Humanist Approach." Artibus et Historiae 14.27 (1993): 153183. Print. http://dx.doi.org/10.2307/1483450

Borgue, Pierre. Leonor Fini ou le théâtre de l'Imaginaire. Paris: Lettres Modernes, 1983. Print.

Breton, André. "Discours sur le peu de réalité" (1924) - "Introduction to the Discourse on the Paucity of Reality." What is Surrealism?: Selected Writings. Ed. Franklin Rosemont. New York: Pathfinder, 1978. 2: 17-28. Print. . Nadja (1928). Trans. Richard Howard. London: Penguin, 1999. Print. . Mad Love (1937). Trans. Mary Ann Caws. Lincoln: U of Nebraska P, 1987. Print.

—. "The Legendary Life of Max Ernst, Preceded by a Brief Discussion on the Need for a New Myth." View 2.1 (April 1942): 5-7. Print.

- "Prolegomena to a Third Surrealist Manifesto." 1942. Manifestoes of Surrealism. Trans. Richard Seaver and Helen R. Lane. Ann Arbor: U of Michigan P, 2000. 279-94. Print.

Brion, Marcel. Leonor Fini et son oeuvre. Paris: Jean-Jacques Pauvert, 1955. Print. 
Burke, Janine. The Sphinx on the Table: Sigmund Freud's Art Collection and the Development of Psychoanalysis. New York: Walker, 2006. Print.

Calas, Nicolas. “Enormous Luminous and Splendid.” View 2.1 (April 1942): 21. Print.

Carrington, Leonora. "Response to 'Enquête'." André Breton, L'Art magique (1957). Paris: Phébus, 1991, 281. Print.

Chadwick, Whitney. Women Artists and the Surrealist Movement. London: Thames \& Hudson, 1991. Print.

Colvile, Georgiana. "Beauty and/Is the Beast: Animal Symbology in the Work of Leonora Carrington, Remedios Varo and Leonor Fini." Surrealism and Women. Ed. Mary Ann Caws, Rudolf Kuenzli, and Gwen Raaberg. Cambridge MA: MIT Press, 1991. 159-81. Print.

"Concerning the Present Day Relative Attractions of Various Creatures in Mythology \& Legend." VVV 2-3 (1943). Rpt. in Surrealist Women: An International Anthology. Ed. Penelope Rosemont. Austin: University of Texas Press, 1998. 166-67. Print.

Constant, Abbé (Eliphas Lévi). Transcendental Magic, Its Doctrine and Ritual. Trans. Arthur Waite. New York: Dutton, n.d. Print.

Éluard, Paul. “Le Tableau Noir.” Donner à Voir. Paris: Gallimard, 1939, 203-04. Print.

Ernst, Max. Preface. Leonor Fini. London: Kaplan Gallery, 1960, N. pag. Print.

Fini, Leonor. Le Livre de Leonor Fini. Lausanne: La Guilde du Livre et les Éditions Clairefontaine; Paris: Vilo, 1975. Print.

Freud, Sigmund. The Interpretation of Dreams (1953). Trans. James Strachey. London: Hogarth Press, 1991. Print. Penguin Freud Library 4.

Gauthier, Xavière. Leonor Fini. Paris: Livre de Poche Paris, 1973. Print.

Givry, Grillot de. Witchcraft, Magic E Alchemy. Trans. J. Courtenay Locke. New York: Dover, 2009. Print.

Guggenheim, Peggy. Out of this Century: Confessions of an Art Addict. London: André Deutsch, Print.

Jelenski, Constantin. Leonor Fini: Painter. New York: CFM Gallery, no date. (Translation of the text from Jelenski, Leonor Fini: Peinture, Paris: Editions Mermoud Vilo, 1980). Print.

Jewell, Edward Alden. "Novelties Offered Among Art Show." New York Times 18 Nov. 1936: 22. Print.

Kochnitsky, Leon. "Shepherdess of the Sphinxes." View 3.2 (June 1943): 49, 66. Print.

Lévi-Strauss, Claude. Myth and Meaning. London: Routledge, 1978. Print.

Mahon, Alyce. Surrealism and the Politics of Eros 1938-1968. London: Thames \& Hudson, 2005. Print.

Michelet, Jules. La Sorcière: The Witch of the Middle Ages. Trans. L. J. Trotter. Fairford: Echo Library, 2010. Print. Trans. of La Sorcière. Paris: Dentu, 1862.

Moravia, Alberto. “Leonor Fini et l'intelligence." Leonor Fini. Edmond Jaloux et 
al. Rome: Edizioni Sansoni, 1945. Print.

Nietzsche, Friedrich. Beyond Good and Evil. Trans. R. J. Hollingdale. Harmondsworth: Penguin, 1973. Print.

Parker, Rozsika, and Griselda Pollock. Old Mistresses: Women, Art and Ideology. London: Routledge, 1981. Print.

Perlman, Marc. "Un entretien avec Leonor Fini." Beaux Arts 27 June 1970. Print.

Réage, Pauline. Histoire d'O (1954). Trans. by Sabine Desire as Story of O. London: Olympia Press, 1994. Print.

—. Histoire d'O. Illus. Léonor Fini. Paris: Le Circle du Livre Précieux, 1962. Print.

Roditi, Edouard. "A Paris Interview with Leonor Fini, Europe's Leading Surrealist Painter." Art Voices 2.10 (Dec. 1963): 204, 221.

Rojas, Carlos. Salvador Dali, or the Art of Spitting on your Mother's Portrait. Trans. Almá Amell. University Park: Penn State UP, 1993. Print.

Sade, D.A.F. de. Juliette. Rome: Colophon, 1944. Print.

Solomon-Godeau, Abigail. Male Trouble: A Crisis in Representation. London: Thames \& Hudson, 1997. Print.

Spector, Jack. The Aesthetics of Freud: A Study in Psychoanalysis and Art. London: Allen Lane, 1972. Print.

Warlick, M. E. Max Ernst and Alchemy: A Magician in Search of Myth. Austin: U of Texas P, 2001. Print.

Webb, Peter. Sphinx: The Life and Art of Leonor Fini. New York: Vendome Press, 2009. Print.

Wilson, Elizabeth. The Sphinx in the City: Urban Life, the Control of Disorder, and Women. Berkeley: U of California P, 1991. Print. 